\title{
GEOLOGY AND DIAMOND DISTRIBUTION OF THE 140/141 KIMBERLITE, FORT À LA CORNE, CENTRAL SASKATCHEWAN, CANADA
}

\author{
Adrian Berryman ${ }^{1}$, Barbara Scott Smith ${ }^{2}$ and Brent Jellicoe ${ }^{3}$ \\ ${ }^{1}$ De Beers Canada Exploration Inc., Canada $;{ }^{2}$ Scott-Smith Petrology Inc., Canada $;{ }^{3}$ Kensington Resources Ltd., Canada
}

\section{INTRODUCTION}

The Fort à la Corne (FALC) kimberlite province comprises at least 70 bodies which are located c. $65 \mathrm{~km}$ east of Prince Albert in central Saskatchewan (Fig. 1). Approximately two-thirds of the kimberlites are known to contain diamonds. In 2000, a review by the FALC Joint Venture (De Beers Canada Exploration Inc., Kensington Resources Ltd., Cameco Corporation and UEM Inc.) prioritised the kimberlites in terms of size, grade and modeled diamond size frequency. The 140/141 kimberlite has been the focus of subsequent evaluation. This paper presents, and discusses, certain aspects of the 2000 and 2001 evaluation programmes which increased the understanding of the geology and, in turn, the diamond distribution within parts of the 140/141 body. The 2002 programme data are not available.

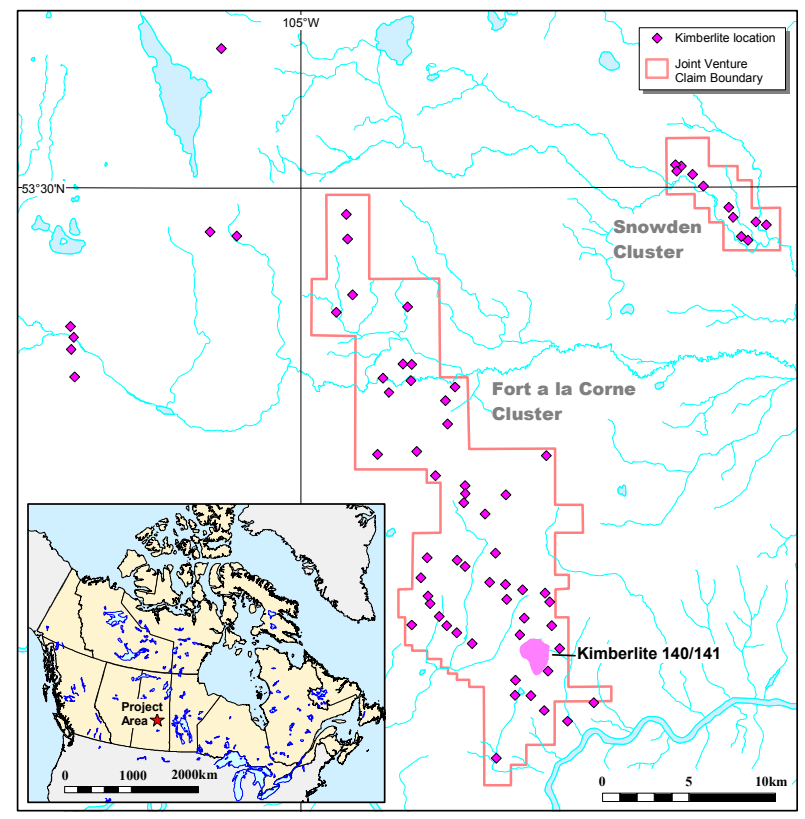

Figure 1: Location of the FALC JV kimberlite 140/141.

\section{GEOLOGICAL SETTING}

Quaternary glacial sediments up to $130 \mathrm{~m}$ in thickness overlie the project area. The FALC kimberlite province occurs within the Interior Platform of North America, close to the northeastern boundary (see Fig. 3 of Jellicoe et al. 1998). Drilling in the FALC area shows that the platform sediments include c. $190 \mathrm{~m}$ of Cretaceous shale, mudstone and sandstone and c. $200 \mathrm{~m}$ of Palaeozoic carbonates and sandstone. The underlying basement is thought to be similar to the Glennie Domain and Chiarenzelli et al. (1996) suggest the latter blankets the apex of a largely buried Archean microcontinent termed the Saskatchewan Craton.

\section{GEOLOGY OF THE FALC PROVINCE}

The FALC province comprises kimberlites that formed near the eastern edge of the Western Canadian Interior Seaway during the Cretaceous, a time of repeated marine transgression and regression. Drilling shows that many of the FALC bodies are relatively thin, but high volume, champagne glass-shaped bodies with diameters ranging up to $2000 \mathrm{~m}$ and thicknesses ranging mainly up to 200m (Fig. 4 in Scott Smith 1996). The bodies formed during periods of seaway lowstand by an overall two stage process: (1) the excavation of shallow, but wide craters and (2) the subsequent infilling by xenolith-poor, crater-facies, dominantly subaerial, primary pyroclastic kimberlite (Scott Smith et al. 1998). Complex internal geology results from coalesced and/or multiple pyroclastic crater infill events. The exposed upper portions of the kimberlites were then subjected to terrestrial and marine sedimentary processes including erosion, resedimentation and burial. Each body is composed of contrasting types of pyroclastic kimberlite reflecting different volcanic histories and, therefore, each body/kimberlite must be considered separately for evaluation purposes. The craters were infilled by subaerial primary pyroclastic processes ranging from Hawaiian- and Strombolian-types to much more explosive kimberlite-specific eruption styles. The latter eruptions are indicated by pyroclastic airfall megagraded beds up to $130 \mathrm{~m}$ in thickness in two of the FALC bodies, one of which is the 140/141 kimberlite. The main group of FALC kimberlites fall in a narrow NNW-SSE trending $32 \mathrm{~km}$ long zone and 140/141 occurs in the southeastern part of the main group of bodies (Fig. 1). 


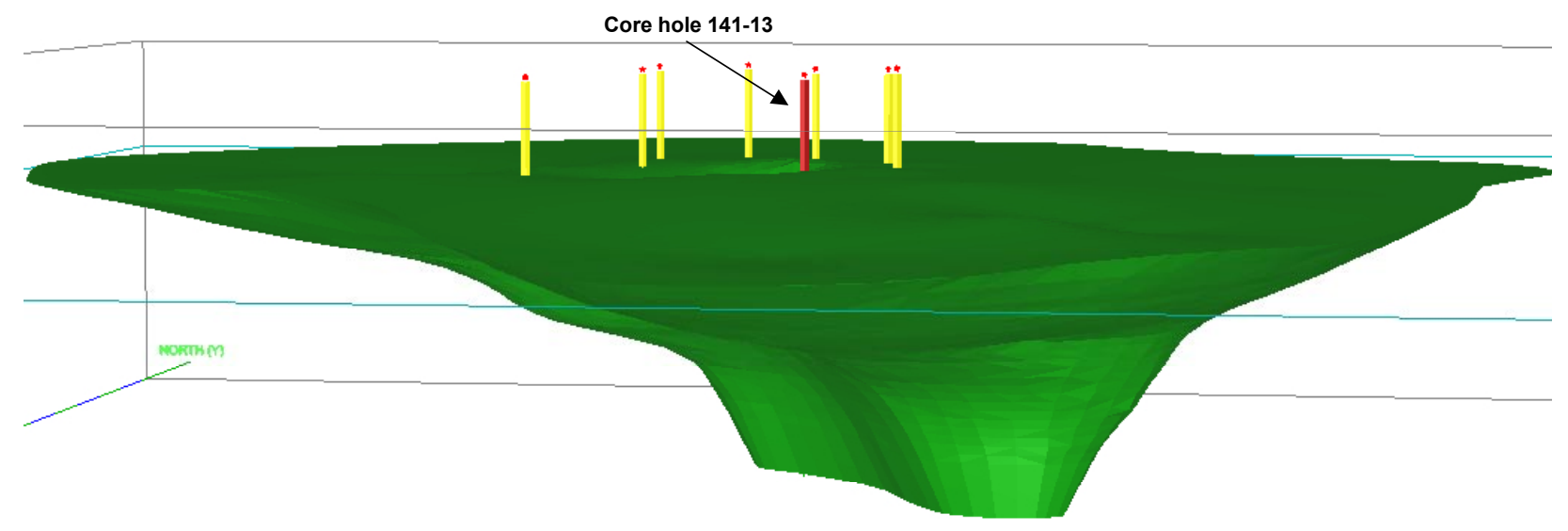

Figure 2: 3D model of the 140/141 kimberlite including drill holes in the study area, looking east.

\section{GEOLOGY OF 140/141}

The 140/141 body is the largest delineated kimberlite in the FALC province, estimated to have an areal extent in excess of 200ha. (Fig 2, Fig. 3 inset). Kimberlite intersections from a total of 21 core holes confirm that this body comprises one irregular, but overall champagne glass-shaped, crater (Fig. 2). Initial geophysical data originally suggested that 140 and 141 were separate bodies but subsequent drilling has suggested a single complex kimberlite. Vertical kimberlite thicknesses encountered during drilling range up to $330 \mathrm{~m}$ and overburden cover averages $105 \mathrm{~m}$ (Fig. 3). Kimberlite intersections $<100 \mathrm{~m}$ occur towards the inferred edge of the body and those $>200 \mathrm{~m}$ occur near the centre suggesting the presence of one, or more, centrally located feeder vents. Pyroclastic kimberlite dominates all drilled intersections, including the deeper material within the probable feeder zone(s). The infilling of the 140/141 crater is complex, and is interpreted as resulting from nested craters and multiple phases of pyroclastic kimberlite. The mega-graded bed is at least $130 \mathrm{~m}$ thick and is a widespread feature within parts of the body. In some instances the mega-graded bed comprises most, or all, of the kimberlite intersection. In other cases it appears to have been preceded by earlier, and/or truncated by later, pyroclastic deposits (Fig. 3). The mega-graded bed consists mainly of pseudomorphed single olivines set in a uniform serpentine inter-clast matrix. Thin kimberlite selvages occur on some olivines. Many intersections of the mega-graded bed display a regular increase in depth with grain size, from very fine to coarse grained kimberlite through to a basal breccia in which xenoliths, predominantly of basement $<10 \mathrm{~cm}$ in size, are abundant (terminology after Field and Scott Smith 1998). Variations in grain size within the overall graded bed sequence occur in the study area. In addition, the grain size, thickness of the basal breccia and thickness of the mega-graded bed all decrease away from the centre of the body (Fig. 3).

\section{MACRODIAMOND DATA FOR 140/141}

Macrodiamonds totaling $63 \mathrm{cts}$ have been recovered from the $140 / 141$ body to date. Individual sample grades vary from 0 to 37 carats per 100 tonnes (cpht). Macrodiamond bulk sample grades from the megagraded bed have been obtained from nine large diameter drill holes, located within the northwest part of the body from an area of $\sim 20$ ha. (Fig. 4 inset). Each drill hole had a nominal diameter of $609 \mathrm{~mm}$ and samples were collected over $12 \mathrm{~m}$ intersections. Diamonds were recovered to $+1 \mathrm{~mm}$. One outlier stone has been omitted from the data presented here. Since sample sizes are small and the area investigated collectively represents only $10 \%$ of the currently modeled kimberlite area, data and interpretations, are considered limited. An overview of the total sample grade per drill hole is given in Fig. 4. Total sample grades per hole, which in some instances include rock types other than the mega-graded bed, range from 11.1 to $2.9 \mathrm{cpht}$. 
A

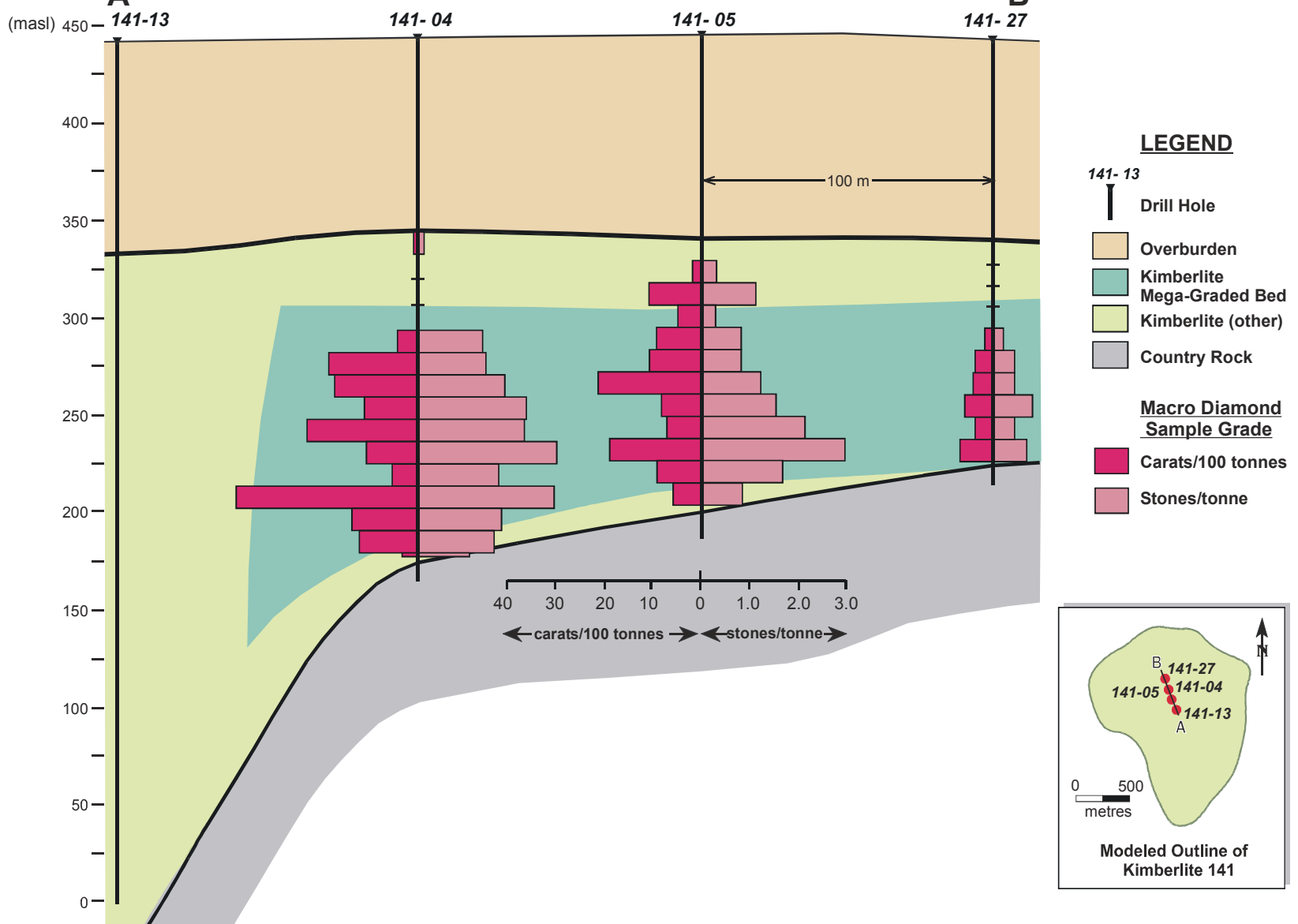

Figure 3: Cross section through part of the mega-graded bed.

A radial cross section through three large diameter holes and a single core hole (Fig. 3) shows the location of the presently defined mega-graded bed within the tested area of the body. The mega-graded bed usually grades upwards into a very fine grained unit in which olivines are not discernible. This unit has been separated from the mega-graded bed (Fig. 3) because it is not clear whether, or not, it forms the upper part of the bed. The macrodiamond sample results for the mega-graded bed, and adjacent kimberlites, are presented in Fig. 3 in terms of cpht and stones/tonne (spt). There is an overall gradual increase in spt with depth within the mega-graded bed. There is a less consistent increase in sample grade or cpht. There are contrasting lower grades in the earlier phases of kimberlite below the mega-graded bed. The overlying very fine-grained material is barren or low grade.

A very different phase of pyroclastic kimberlite is present in core hole 141-13. This kimberlite appears to form a younger nested crater (cf. Webb et al. this volume) within the mega-graded bed (Fig. 3). This

drillhole location has not been bulk sampled. This core hole, however, contains the deepest intersection of

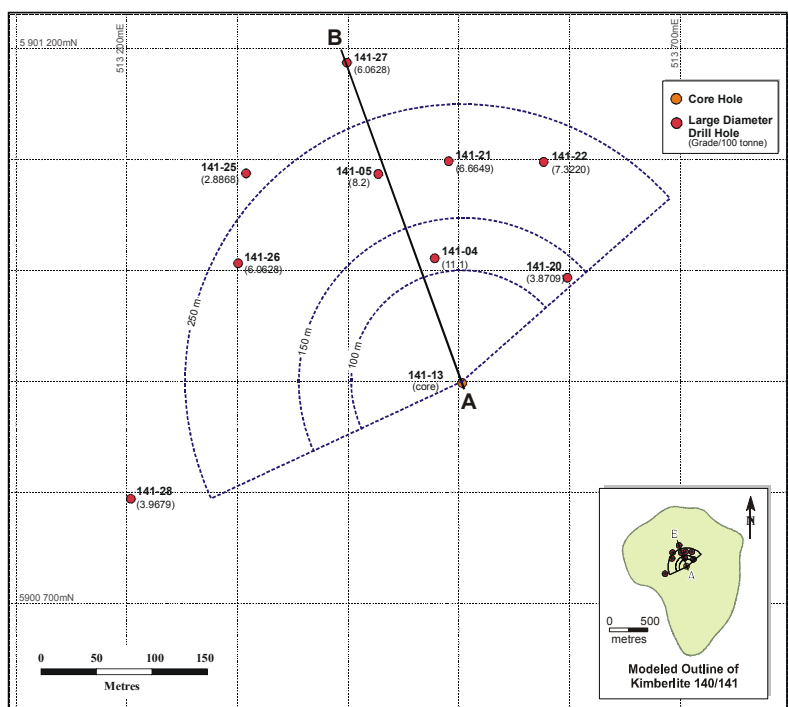

Figure 4: Location and total sample grade of the large diameter drill holes, which intersected the mega-graded bed within the study area. Cross section A-B shown in Fig. 3. 
kimberlite (>330m; Figs. 2 and 3) encountered to date. This hole also occurs towards the centre of the body where the kimberlite overall appears to be thicker (Fig. 2 ), a likely location for feeder vents. The location of drill hole 141-13, therefore, has been used as a reference point to illustrate, and further interpret, the macrodiamond data. The macrodiamond sample data are sub-divided into three groups in terms of their distance (radius) from the reference point: $100-150 \mathrm{~m}$, $150-250 \mathrm{~m}$ and $>250 \mathrm{~m}$ as shown in Fig. 4 . Both total

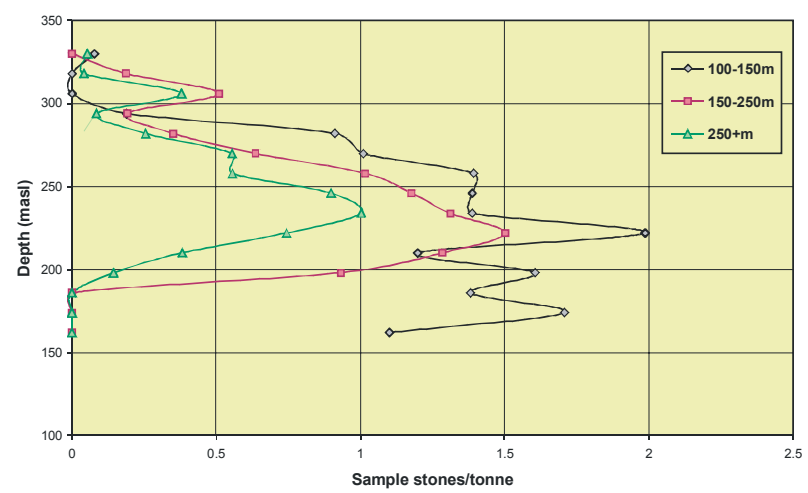

Figure 5: Total sample stones per tonne grouped by radial distance from 141-13 (see Fig 4).

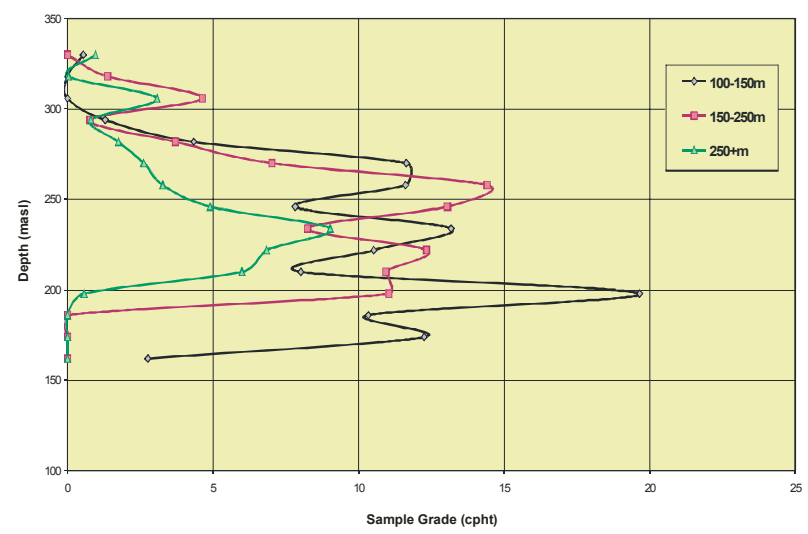

Figure 6: Total sample grade grouped by radial distance from 141-13 (see Fig 4).

macrodiamond sample grade $(+1.0 \mathrm{~mm})$ in $\mathrm{cpht}$ and $\mathrm{spt}$ are plotted against depth corrected to a common height datum in metres above sea level (masl; Figs. 5 and 6). As illustrated in Fig. 3, the upper sub-glacial surface of the 140/141 kimberlite occurs at a depth of c. $105 \mathrm{~m}$ from surface or 342 masl. Each data point marks the bottom of a datum-corrected $12 \mathrm{~m}$ large diameter minibulk sample. Figs. 5 and 6 show that, in all three groups, there is an overall gradual increase in spt with depth from $300 \mathrm{~m}$ masl (which is the top of the presently defined mega-graded bed cf. Fig. 3) to $220-230 \mathrm{~m}$ masl which approximates the base of the mega-graded bed (cf. Fig. 3). An increase in sample grade within the mega-graded bed is less well defined. These figures additionally show that there is an increase in spt with proximity to the reference point, and a similar, if less well defined, increase in sample grade. The earlier contrasting phases of kimberlite that occur below the mega-graded bed have different, and apparently lower, grades.

\section{DISCUSSION}

The 140/141 kimberlite comprises a large, irregular champagne glass-shaped crater with a complex infill of different phases of pyroclastic kimberlite dominated by one pyroclastic airfall mega-graded bed of significant thickness (up to $130 \mathrm{~m}$ ) which was then cut by a central younger nested crater of different kimberlite. Pyroclastic graded beds of such thicknesses were previously unknown in the geological record, thus the interpretation was controversial. A comparable $>40 \mathrm{~m}$ mega-graded bed, however, has since been recognised at Diavik, Lac de Gras, NWT (Graham et al. 1999). The results presented here show a relationship between the number of macrodiamonds and the grain size of the kimberlite with depth. The data supports the proposed mega-graded bed and in turn, these conclusions are useful in understanding the macrodiamond distribution within the studied area of the body.

\section{CONCLUSIONS}

The results of the recent 2000 and 2001 evaluation programmes by the Fort a la Corne Joint Venture on the greater than 200 ha. 140/141 body focused on an area of approximately $20 \mathrm{ha}$. There is a probable correlation between kimberlite geology and macrodiamond distribution. Within this area of investigation, the complex infill of the shallow, but large volume, 140141 crater is dominated by one pyroclastic airfall megagraded bed of at least $130 \mathrm{~m}$ in thickness. The minibulk macrodiamond sample data show that the number of stones per tonne decrease with decreasing kimberlite grain size and decreasing depth within the mega-graded bed. The diamond data thus provide support for the occurrence of the geologically exceptional mega-graded bed, which is the thickest known. This investigation shows the importance of integrating kimberlite geology with macrodiamond sampling data in the evaluation of a mineral deposit. This geological/macrodiamond grade model can be used to further investigate this mineral 
deposit and other kimberlites in the Fort à la Corne cluster.

\section{REFERENCES}

Chiarenzelli, J.R., Aspler, L.B., Villeneuve, M., 1996. Characterisation, Origin and Paleaproterozoic history of the Saskatchewan Craton and possible implications for Trans-Hudson Orogen. In: Lithoprobe TransHudson Orogen Transect. Report of Sixth Transect Meeting, Report No. 55, Univ. Sask., pp. 26-38.

Field M. and Scott Smith B.H. 1999. Contrasting geology and near-surface emplacement of kimberlite pipes in Southern Africa and Canada. In: Proceedings of the Seventh International Kimberlite Conference, Volume 1, p. 214-237.

Field M. and Scott Smith B.H. 1998b. Textural and genetic classification schemes of kimberlites: a new perspective. Extended Abstracts of the Seventh International Kimberlite Conference, Cape Town, South Africa, 1998, 214-216.

Graham I., Burgess J.L., Ravenscroft P.J., Thomas E., Doyle B.J., Hopkins R. and Armstrong K.A. 1999. Exploration history and geology of the Diavik kimberlites, Lac de Gras, Northwest Territories, Canada. Proceedings of the Seventh International Kimberlite Conference, Volume 1, p. 262-279.

Jellicoe, B.C., Robertshaw, P., Williamson, P. and Murphy, J., 1998. Summary of Exploration Activities and Results for the Fort à la Corne Diamond Project, Saskatchewan. In Summary of Investigations 1998, Saskatchewan Geological Survey, Sask. Energy Mines, Misc. Rep. 98-4, pp. 144-157.

Scott Smith, B.H. 1996. Kimberlites. In Mitchell, R.H. (Ed.), Undersaturated Alkaline Rocks: Mineralogy, Petrogenesis and Economic Potential. Mineralogical Association of Canada, Short Course Volume 24, p.217-244).

Scott Smith, B.H., Orr, R.G., Robertshaw P. and Avery R.W. 1998. Geology of the Fort a la Corne kimberlites, Saskatchewan. Extended Abstract of the Seventh International Kimberlite Conference, Cape Town, South Africa, 1998, p. 772-774.

Webb K.J., Scott Smith B.H., Paul, J.L. and Hetman, C.H. This volume. Geology of the Victor Kimberlite, Northern Ontario, Canada. 